\title{
COMPUTER MODELLING OF GROUNDWATER OCCURRENCE USINGGEOPHYSICAL PARAMETERS - A CASE STUDY FROM GANGAIKONDAN AND MANUR BLOCK, TIRUNELVELI DISRTICT, TAMILNADU, SOUTH INDIA \\ R.Soundar Rajan \\ CSIR-National Geophysical Research Institute, Hyderabad 500 007, India
}

\author{
R. Ramesh, Ganapathy Subramanian, Visagan Sundararajan \\ National College, \\ Tiruchirapalli 620 001, India
}

\begin{abstract}
Underground water resources can be identified using many geological, geomorphological, structural and lithological criteria. The Geophysical methods are more useful, indeed, tell us about the exact disposition of the concealed underground water, its quantity and quality. Among the various geophysical techniques, Electrical Resistivity methods are widely used and producing appreciable results. Despite sufficient rainfall, large part of India suffers from water scarcity. Ground water occurs in weathered or semi-weathered/fractured layers in hard-rock areas whose thickness varies, in general, from $5 \mathrm{~m}$ to $20 \mathrm{~m}$. In the present study, an attempt has been made to delineate various subsurface layers and pick out suitable locations for drilling of borewells or construction of open wells for assessment of groundwater availability in Gangaikondan Panchayat (Tirunelveli District, Tamilnadu) which shows various groundwater potential zones.
\end{abstract}

Key words: Groundwater, Geophysical parameters, Computer Modelling, VES.

\section{INTRODUCTION}

The study area is forming a part of Gangaikondan Panchayat, located in Manur Block, Tirunelveli Taluk, Tirunelveli district, Tamilnadu (Fig1). Gangaikondan is a panchayat town in Tirunelveli district and a suburb of Tirunelveli city in the state of Tamil Nadu, India. It is located about $20 \mathrm{~km}$ north of Tirunelveli Corporation on the way to Madurai on NH 7. It is one the industrial hubs of Tirunelveli. The Study area is approximately one square $\mathrm{km}$ of land, characterized with leveled topography and Survey of India Toposheet No. 58 $\mathrm{H} / 13$ and lies between latitude $\mathrm{N}^{\circ} 49^{\prime} 21^{\prime \prime}$ to $\mathrm{N} 8^{\circ} 51^{\prime} 25^{\prime \prime}$ and longitude E $77^{\circ} 46^{\prime} 21^{\prime \prime}$ to E $77^{\circ} 049^{\prime} 54^{\prime \prime}$. Location of the study area is shown below in Figure 1. 
International Journal of Engineering Applied Sciences and Technology, 2019

Vol. 4, Issue 3, ISSN No. 2455-2143, Pages 249-258

Published Online July 2019 in IJEAST (http://www.ijeast.com)

Fig.1 India map, Tamil Nadu, Tirunelveli district map, Manur Block
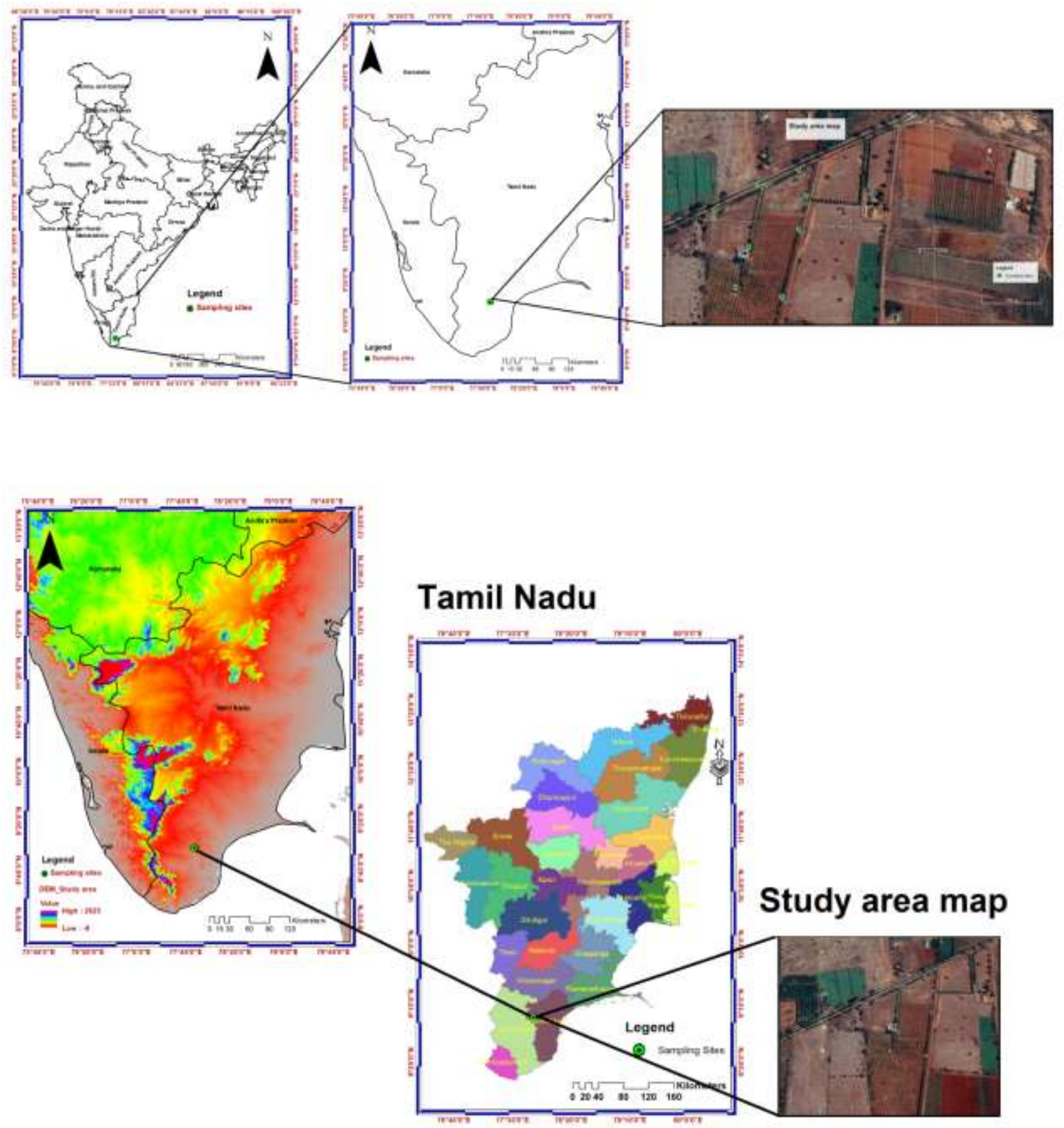
International Journal of Engineering Applied Sciences and Technology, 2019

Vol. 4, Issue 3, ISSN No. 2455-2143, Pages 249-258

Published Online July 2019 in IJEAST (http://www.ijeast.com)

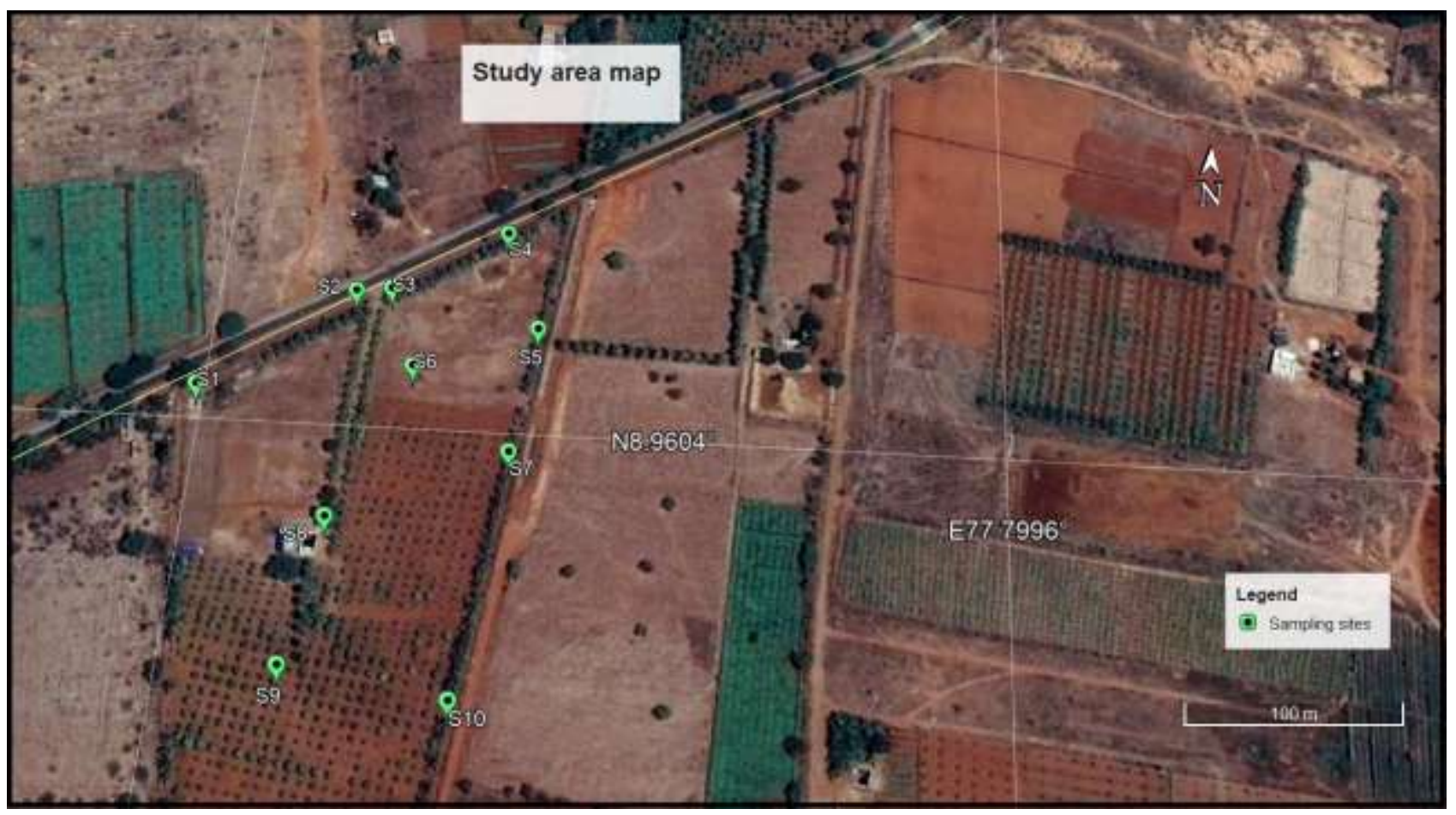

Fig.2 Location Map of the study area, Manur Block

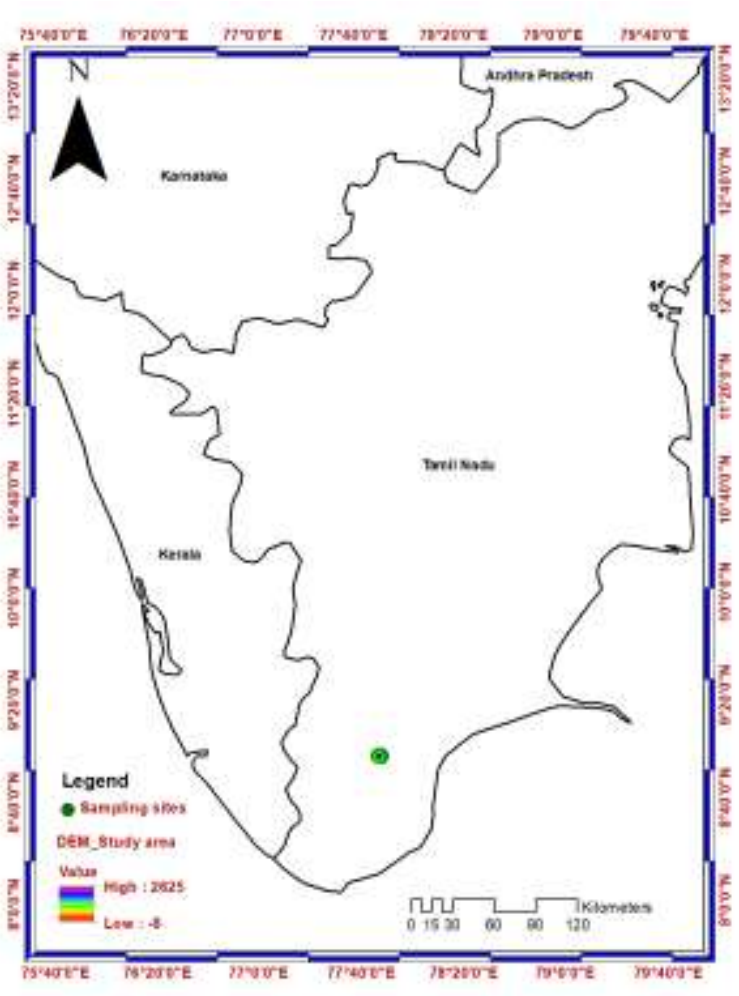

II. GEOLOGICAL AND CLIMATE SETTINGS OF THE STUDY AREA

2.1 Physiography:The study area is a plain terrain with gentle slope towards eastern direction. The river Chittar which is tributary of Tamiraparani

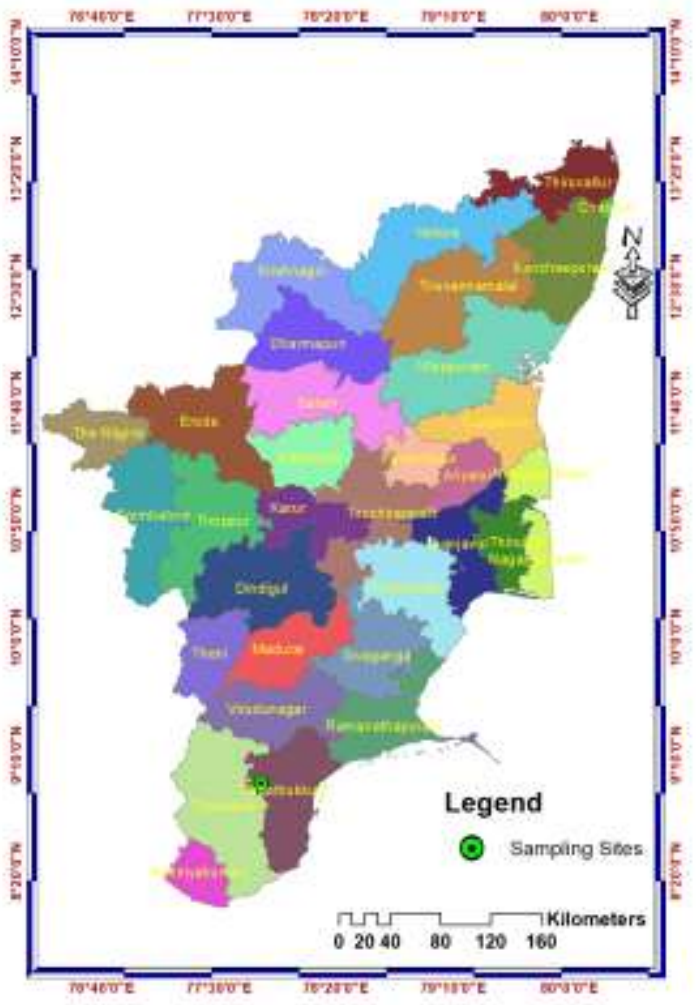

runs from west to east in the northern part of the area. The main river Tamiraparani runs from west to east in the southern part of the study area.The Gangaikondan tank is main recharge of the study area. 
2.2 Soil: Soil of entire area is less fertile. The area is partially occupied by Red Loamy \& Black cotton soil. Soil in that area was general loose in texture and well drained. Less quantity of iron concentrations is present in the soil.

2.3 Agriculture: With adverse climate, having plot topography, unreliable precipitation and light soil texture, the cropping pattern of the district mainly depend on rainfall, as it is the main source of irrigation along with medium irrigation, minor irrigation and lift irrigation. People mainly grow Ground net, cotton as the major crop in their fields in Monsoonseason. Rice is also grown by farmers of that region.

2.4 Temperature: The Manur block has a semi arid sub tropical climate. The high relative humidity prevails throughout the year between 60 and $75 \%$. The climate of the area is been aggressively hot during summer with high Wind. The maximum temperature begins to rise rapidly during the month of May. The annual mean minimum and maximum temperature are $23^{\circ} \mathrm{C}$ and $29^{\circ} \mathrm{C}$ respectively. During the summer maximum temperature is recorded around $36^{\circ} \mathrm{C}$. The weather becomes more pleasant with the approach of the monsoon in June and remains as such up to the end of October.

2.5 Rainfall: The Manur block have one raingauge station. The area receives rainfall mainly from North East monsoon (Oct to Dec). The contribution from South west monsoon, winter rainfall and hot weather rainfall is marginal. The 50 Years normal rainfall during NE monsoon is $443.8 \mathrm{~mm}$ and that of SW monsoon is $136.2 \mathrm{~mm}$. Normal winter rainfall ( Jan - Feb) is 48.3 mmand normal hot weather rainfall (Mar-May) is $115.9 \mathrm{~mm}$. The annual rainfall is $744.2 \mathrm{~mm}$. The annual rainfall during the last 10 years from 301.4 to $821.7 \mathrm{~mm}$.

2.6 Geology: The geology of the Manur block mainly comprises of gneissic rock. It is also chiefly underlain by the crystalline rocks of Archaean age consisting of Gneisses, Calc gneiss, Calc granulite, Crystalline Limestone, Quartzites and Charnockites. The quartzite belts occur in sparse and they trend NW to SE direction. The crystalline limestone and epidotes are also seen near Sankar Nagar which are trending parallel to each other. The charnockites are observed in the western part of the block. The sedimentary formations like clay, sandy clay are occurring in the southern part like river courses.

2.7 Geomorphology:Geomorphologically this block is a plain terrain with gentle slopes. Major geomorphic units are plains consisting of red soil drained by Tamiraparani River. Flood Plains are found along the river. But Chittar river banks are covered by the shallow pediments. Generally buried pediment units are observed near tanks and other water bodies in the Ayacut areas.

2.8 Drainage:The Tamiraparani River and its tributaries form the main drainage system in Tirunelveli district. The overall drainage pattern of the district on a regional scale is dendritic to subparallel. The river Chittar which is tributary of Tamiraparani runs from west to east in the northern part of the Manur block. The main river Tamiraparani runs from west to east in the southern part of the study area.

2.9 Slope:The Manur block has almost the entire portion (98\% of the block area) falls under nearly level (1-3\%). The remaining portion falls under moderately steep to steep sloping (15-35\%) category.

2.10 Hydrogeology: Ground water is extracted through open-wells meant for irrigation and drinking purposes. In some places, water is extracted through borewells for drinking purposes. The Study area was hydrogeological sub partitioned into united, semi-combined \& unconsolidated establishments. The combined arrangements incorporate hard crystalline and minimized sedimentary rocks although semimerged establishments incorporate weathered and friable sedimentary and inexactly established Tamiraparani bunks. The water-bearing properties of crystalline formations which lack primary porosity depend on the extent of development of secondary intergranular porosity. The occurrence and movement of ground water in these rocks are under unconfined conditions in the joints \& fissures and dependent on the nature and extent of pores and interconnection of fractures zones. The morpho-tectonic analysis of the crystalline tract indicates the presence of deep seated tensile and shear fractures particularly along the fold axes. These tension joints and fractures and shear fractures at deeper depth of 30 to $100 \mathrm{~m}$ have been acting as conduits for ground water movement.

\section{MATERIALS AND METHODS}

\subsection{Field Survey}

Field surveys were made during the years 2017 and 2018 at 10 (Ten) locations of the sub-basin to collect ground water information using Electrical resistivity tests. Vertical electrical soundings using Schlumberger array were carried out with maximum to half current electrode separation $(\mathrm{AB} / 2)$ more than $150 \mathrm{~m}$ which is highly used in groundwater exploration study. Apparent resistivity at sounding stations is plotted against the 


\section{International Journal of Engineering Applied Sciences and Technology, 2019 \\ Vol. 4, Issue 3, ISSN No. 2455-2143, Pages 249-258 \\ Published Online July 2019 in IJEAST (http://www.ijeast.com)}

corresponding half electrode spacing to look for weaker or stronger water potential zones. The result which was obtained had been analyzed and plotted in IPI2win software which is mainly used by the geo-physic researchers. Detail of the resistivity site and the outcome results such as obtained error, types of curve used, probable aquifer thickness, and classes of aquifer.

\section{Vertical Electrical Sounding (VES)}

Aim of this study was to determine feasibility by using one of VES methods-i.e. the Schlumberger array-for identifying various groundwater potential zones in Kayattar, Tuticorin District, Tamilnadu, India. The VES systems were presented by Schlumberger in 1934. From that onward, awide varity of VES system were created (Keller and Frischknecht, 1966, pp. 90-196), yet the Schlumberger exhibit stayed as the best show for depth sounding.

A series of measurements of resistivity are made by increasing the electrode spacing in successive steps about a fixed point. This method of vertical exploration is known as the expanding electrode method, "Resistivity sounding" or "Depth probing" or vertical electrical sounding (VES). The apparent resistivity values obtained with increasing values of electrode separation are used to estimate the thickness and resistivities of the subsurface formations. VES mainly employed in groundwater exploration to determine the disposition of the aquifers.

\subsection{Geoelectrical Parameters}

The main objective of the quantitative interpretation of VES curve is to obtain the geoelectrical parameters. A geoelectric layer is called by its fundamental characters, resistivity ' $\rho$ ' and thickness ' $h$ '. These two parameters are called the primary geoelectrical parameters. The secondary geoelectrical are also important to describe the geoelectric section consisting of several layers. The longitudinal $(\mathrm{S})$ and the total transverse $(\mathrm{T})$, transverse resistivity $(\mathrm{T} / \mathrm{h})$ an isotropy $(\lambda)$ are called the secondary geoelectrical parameters. The (Fig.2) Shows columnar prism used in defining geoelectric parameters.

\section{RESULTS AND DISCUSSIONS}

The field data were interpreted and processed qualitatively and quantitatively by using partial curve matching techniques and computer to obtain the resistivity values of different subsurface layers and their corresponding thickness (Table 1).

The interpretation of resistivity data is done in two stages, 1 . Processing of data to get the geoelectric parameters of apparent resistivities, depth/thickness and 2. These parameters are used to infer the nature of surface lithology on the basis of the local geological knowledge and correlation studies.

\subsection{Quantitative Approach}

The quantitative approach is to get the geoelectric parameters i.e., the true resistivity, layer thickness/ depth etc. The VES data of the study area have been qualitatively and quantitatively analyzed and interpreted using software IPI2 WIN version 3.1.0, a Russian software package of Moscow University. By using Surfer, resistivity contour maps have beengenerated for different depth ranges to identify and demarcate the anomaly zones. The IPI2 WIN software is used to prepare the VES curves Pseudo sections, Geoelectric profiles and Geoelectric sections. The 4 numbers of Pseudo sections along 4 profiles (Fig 3-6) in different directions and have prepared by considering geoelectrical parameters for all the 10 VES curves.

Table 1: Summary of VES data interpretations with positions

\begin{tabular}{|c|c|c|c|c|c|c|c|c|c|c|}
\hline \multirow{2}{*}{$\begin{array}{l}\text { VES } \\
\text { No }\end{array}$} & \multicolumn{5}{|c|}{ Resistivity ( $\Omega \mathrm{m})$} & \multicolumn{5}{|c|}{ Layer Thickness (m) } \\
\hline & $\rho 1$ & $\rho 2$ & $\rho 3$ & $\rho 4$ & $\rho 5$ & h1 & h2 & h3 & h4 & h5 \\
\hline 1 & 49.3 & 179 & 32.8 & 2600 & 36.4 & 1.38 & 3.35 & 8.1 & 15.7 & 36.2 \\
\hline 2 & 23.5 & 201.0 & 560.0 & 1720.0 & 319.0 & 2.57 & 12.9 & 21.7 & 38.8 & 72.0 \\
\hline 3 & 41.5 & 172.0 & 43.3 & 1652.0 & 500.0 & 2.09 & 3.68 & 9.76 & 21.7 & 31.75 \\
\hline 4 & 62.6 & 11.9 & 98.3 & 1404.0 & 6057.0 & 2.02 & 4.04 & 19.8 & 35.0 & 80.0 \\
\hline 5 & 559 & 4.42 & 46.9 & 22.3 & 2464.0 & 1.35 & 1.88 & 6.36 & 15.2 & 23.8 \\
\hline
\end{tabular}


International Journal of Engineering Applied Sciences and Technology, 2019

Vol. 4, Issue 3, ISSN No. 2455-2143, Pages 249-258

Published Online July 2019 in IJEAST (http://www.ijeast.com)

\begin{tabular}{|c|c|c|c|c|c|c|c|c|c|c|}
\cline { 7 - 11 } & 54.0 & 11.4 & 14.6 & 3146.0 & 105.0 & 3.14 & 8.13 & 10.0 & 20.0 & 37.6 \\
\hline 7 & 51.3 & 55.0 & 124.0 & 54.5 & 1082.0 & 5.72 & 6.22 & 10.7 & 22.2 & 55.5 \\
\hline 8 & 43.4 & 19.2 & 65.0 & 1873.0 & 803.0 & 2.11 & 4.55 & 17.9 & 19.0 & 3.7 \\
\hline 9 & 65.5 & 36.6 & 130.0 & 909.0 & 38.6 & 4.67 & 7.94 & 9.29 & 21.0 & 60.3 \\
\hline 10 & 23.1 & 66.0 & 9.17 & 5418.0 & 75.8 & 1.32 & 3.36 & 8.30 & 14.4 & 41.5 \\
\hline
\end{tabular}

Table 2: Qualitative analysis of curve types where $\rho$ represents resistivity of the layer

\begin{tabular}{|c|c|c|c|}
\hline VES & Curve type & $\begin{array}{c}\text { Curve } \\
\text { Characteristics }\end{array}$ & No. of Geo-electric Layer \\
\hline 1 & $\mathrm{H}$ & $\rho 1>\rho 2<\rho 3$ & 3 \\
\hline 2 & $\mathrm{~A}$ & $\rho 1<\rho 2<\rho 3$ & 3 \\
\hline 3 & $\mathrm{AK}$ & $\rho 1<\rho 2<\rho 3>\rho 4$ & 4 \\
\hline 4 & $\mathrm{AK}$ & $\rho 1<\rho 2<\rho 3>\rho 4$ & 4 \\
\hline 5 & $\mathrm{AK}$ & $\rho 1<\rho 2<\rho 3>\rho 4$ & 4 \\
\hline 6 & $\mathrm{H}$ & $\rho 1>\rho 2<\rho 3$ & 3 \\
\hline 7 & $\mathrm{H}$ & $\rho 1>\rho 2<\rho 3$ & 3 \\
\hline 8 & $\mathrm{~A}$ & $\rho 1<\rho 2<\rho 3$ & 3 \\
\hline 9 & $\mathrm{~A}$ & $\rho 1<\rho 2<\rho 3$ & 3 \\
\hline 10 & $\mathrm{H}$ & $\rho 1>\rho 2<\rho 3$ & 3 \\
\hline
\end{tabular}

Isoresistivity Maps

The Isoresistivity maps are the resistivity contour maps and Iso is a Greek word meaning 'equal' and contours are imaginary lines on map connecting equal value. The values may be of any parameter, like elevation, TDS, layer thickness and so on. Accordingly the layer thickness contour maps of the study area have been generated incorporating all the 10 VES data for different formation with their co-ordinates, joining equal layer thickness of the depth of investigation. The layer thickness contour maps for first layer, second layer, third layer were prepared. The difference between two consecutive contour lines is termed the contour interval. The Isoresistivity maps can be used for qualitative interpretation of the groundwater and by quantity by demarcating the low and high layer thickness anomalous zones. This also further helps to delineate the granular and clayey zones in weathered, fractured and massive rock zones in crystalline terrains. The method of Qualitative and Quantitative interpretations helps us identify good ground water potential zones. There are different curve types inferred during the geophysical interpretations. The general trend of the aquifer is expected to be $\mathrm{K}$ where in the resistivity values keep on decreasing with depth or decreases in the deeper aquifer. Where the first layer has low resistivity values than the under laying layers. All these locations with A \& K type curve.

\section{Geoelectrical Profiles}

All the 10 VES locations studied were made into 5 profiles covering the entire study area (Fig 7, 8, 9, 10 and 11) with definite orientations, traversing different geological formations to project a two dimensional subsurface geoelectric section along that profile. All these geoelectric profiles have been generated by IPI 2 WIN software package. The geoelectric profiles are nothing but the geoelectrical section of each VES locations united into one profile with a definite directional orientation. Each geoelectric profile has two 


\section{International Journal of Engineering Applied Sciences and Technology, 2019 \\ Vol. 4, Issue 3, ISSN No. 2455-2143, Pages 249-258 \\ Published Online July 2019 in IJEAST (http://www.ijeast.com)}

profiles namely Pseudo section displaying the apparent resistivities at different depths below ground level from surface to $100 \mathrm{~m}$ depth and the other section with thickness of different geoelectric layers below ground level. The resistivity sections only reflect the interpreted subsurface lithology. The ordinate ' $\mathrm{X}$ axis' represent the distance of traverse and the abscissa ' $Y$ axis' represent the depth in meters below ground level.

\section{Profile -I}

The profile I located in north side of study area. The river flows from the south east to eastern parts of the study area. The location considered in this profile is the upstream to downstream side of the study area. The traverse of the profile is from west to eastern part of the study area (fig-1).

Fig. 3:Resistivity pseudo section and 2D inverse model (Profile 1)

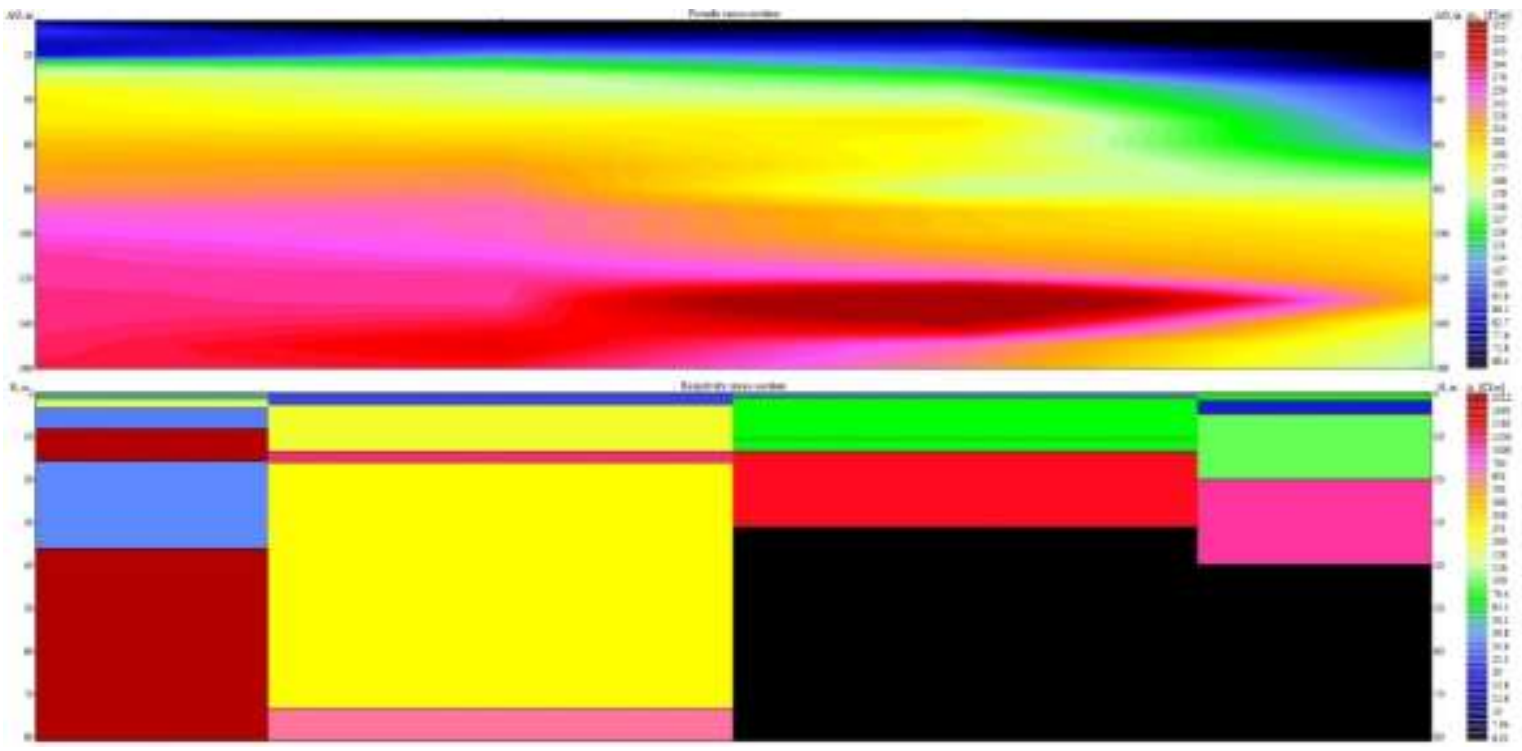

Profile -II

The profile II located in south side of study area. The location of this profile includes upstream side of the study area. The traverse of the profile is west to eastern part of the study area.

Fig. 4: Resistivity pseudo section and 2D inverse model (Profile 2)

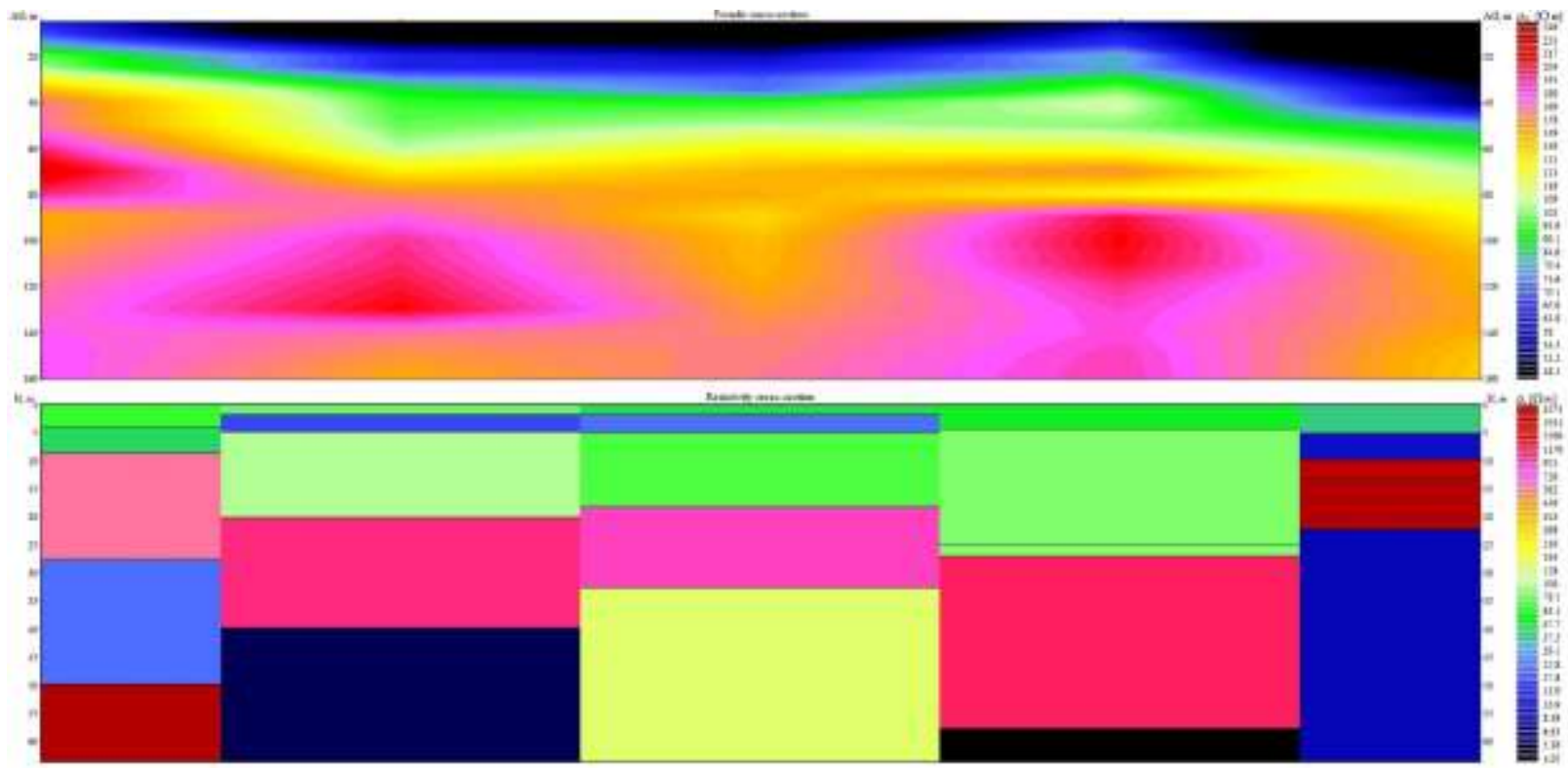




\section{International Journal of Engineering Applied Sciences and Technology, 2019 Vol. 4, Issue 3, ISSN No. 2455-2143, Pages 249-258 \\ Published Online July 2019 in IJEAST (http://www.ijeast.com)}

\section{Profile - III}

The profile III located in midpoint of study area. The locations considered for this profile are south to north.

Fig. 5:Resistivity pseudo section and 2D inverse model (Profile 3)

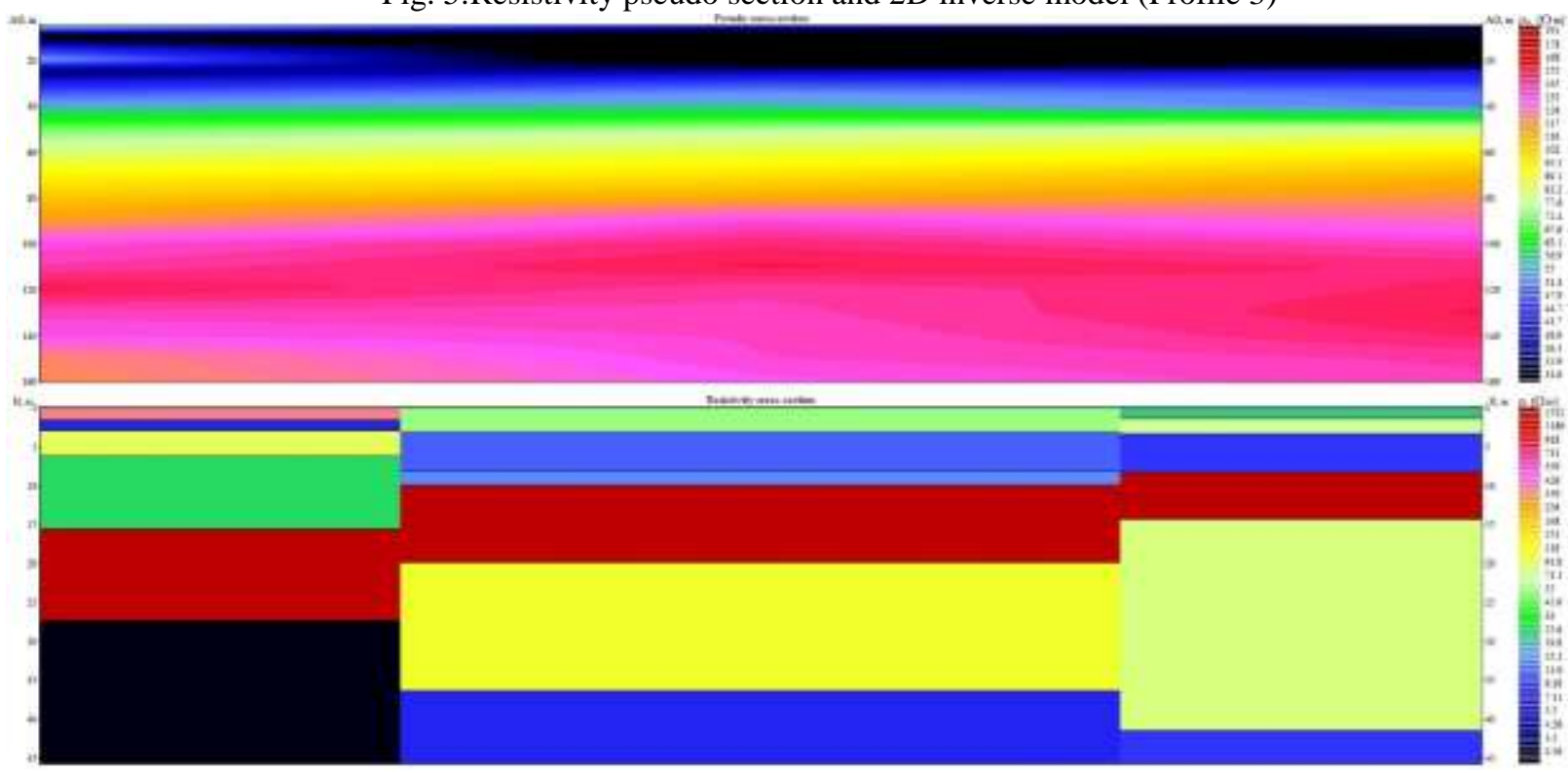

\section{Pseudo Section with Resistivity Section}

The central part of the profile figure exhibits low resistivity clay from the central part to eastern sides. Since the profile is along the river course, the low resistivity anomalies may be due to the presence of alluvium, clay and weathered bed rock. The higher resistivity [30 to $140 \Omega \mathrm{m}$ ] may be due to the presence of sand or massive.

The minimum and maximum apparent resistivity is $4 \Omega \mathrm{m}$ and $140 \Omega \mathrm{m}$ and all the VES are multilayered geoelectrical sections. The minimum and maximum numbers of layers are 3 and 4 . The central portion of the profile shows the least resistivity in the range of $2.87 \Omega \mathrm{m}$ to $23.5 \Omega \mathrm{m}$, indicating highly conducting formations like clay, clayey sands or formations with high conductive water. Based on the geological, hydrogeological and geoelectrical investigations, the entire profile is a hard rock formations (consolidated) represented by minor Lithological units of alluvium, clay, sand which are resulted by weathering and gneiss with good ground water potential.

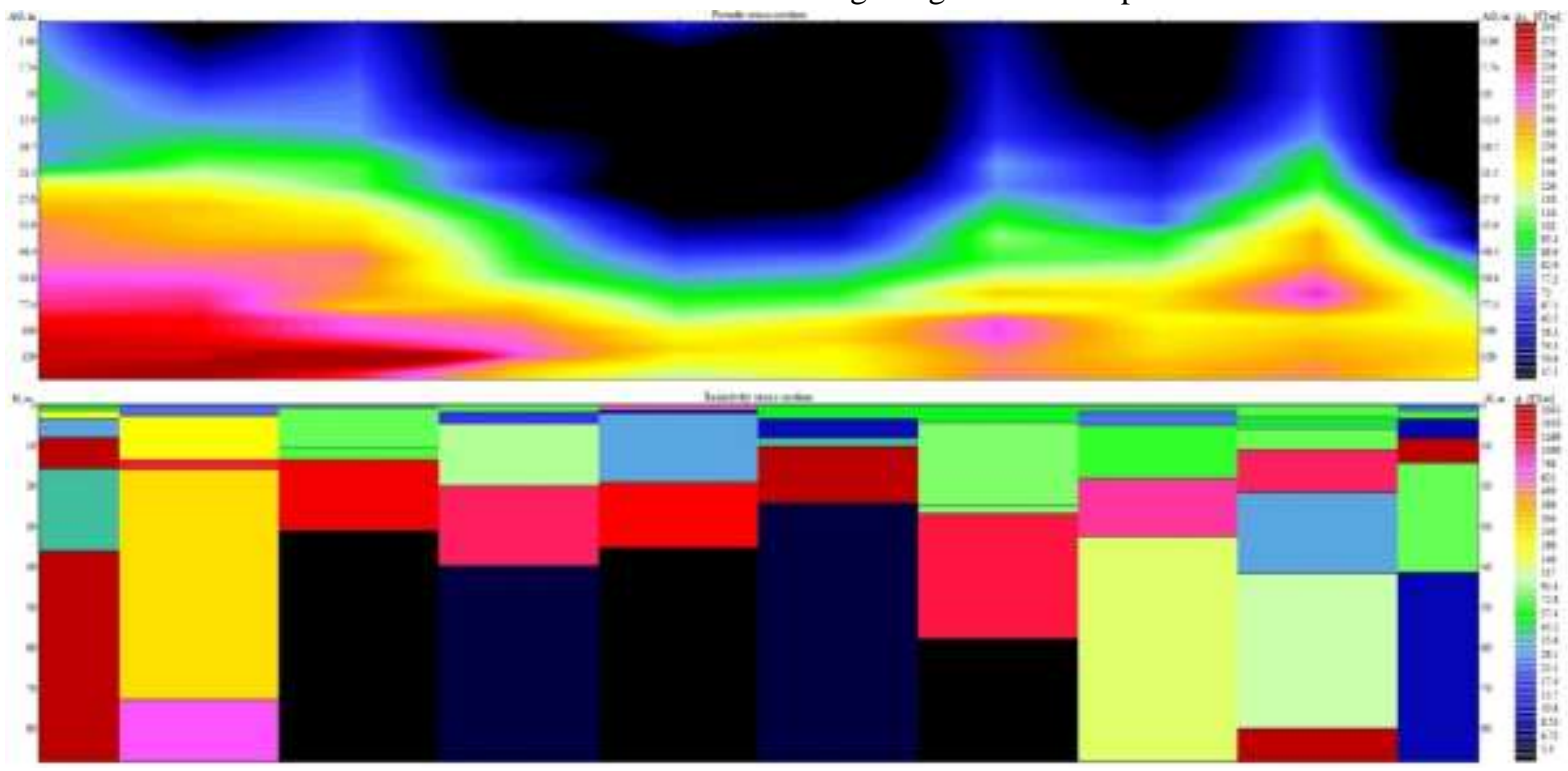

Fig. 6: Resistivity pseudo section and 2D inverse model (Profile 4) 
International Journal of Engineering Applied Sciences and Technology, 2019

Vol. 4, Issue 3, ISSN No. 2455-2143, Pages 249-258

Published Online July 2019 in IJEAST (http://www.ijeast.com)

\begin{tabular}{|c|c|c|}
\hline S.No & VES ID & Groundwater potential zone \\
\hline 1 & VES-9 \& VES-10 & Very good \\
\hline 2 & VES-1 \& VES-6 & Good \\
\hline 3 & VES-3,VES-5 \& VES-7 & Moderate \\
\hline 4 & VES-2,VES-4 \& VES-8 & Poor \\
\hline
\end{tabular}

Table: 3. Assigned features for the groundwater potential zoning.

\section{CONCLUSION}

In the study area, the empirical data acquired from the field data have been tabulated, processed and interpreted. The quantitative methods of interpretational techniques have been followed for delineating the different subsurface layers. The individual thickness and corresponding true resistivity values have been cull-out and furnished in the Table (3).

From the quantitative analysis and interpretations, concluded the following results.

$\checkmark \quad$ Ten vertical electrical soundings were carried out to determine the underground water potential and the Lithological setting in terms of aquifer distribution around the study area.

$\checkmark$ The present data from VES1, VES6, VES7, VES9 and VES10 were interpreted and found to be H Type. Here the aquifer resistivity is low to moderate. The VES2 and VES8 were interpreted and found to be A type and remaining VESs are AK type.

$\checkmark$ The study has shown that the region is underlain by 3 to 4 geoelectric layers within the depth penetrated.

$\checkmark$ The groundwater potential of in and around Gangaikondan Panchayat, Manur Union (Table 3) reveals four distinct classes (zones) representing 'Very good', 'good', 'moderate' and 'poor' groundwater potential in the area.

$\checkmark$ The Very good groundwater potential zone mainly encompasses good be recharged along the Precipitation and Nearby Tanks and also good water bearing formation.

$\checkmark$ The good groundwater potential zone mainly covered by regions with groundwater in joints \& some quantity of ground water will be recharged held in the weathered zone subsequently fractured planes.

$\checkmark$ It's also identified that Groundwater occurs under water table conditions the depth of water table ranges from 7 to 12 m. $\checkmark$ Groundwater recharge takes place through precipitation of rain water aided by morphological features of ground surface around the major river systems.

$\checkmark \quad$ It's also demarcated that the areas in the upper part of the study area is not suitable for groundwater storage and also indicates the deep availability of water very below the ground.

$\checkmark \quad$ The poor groundwater potential is due to the higher slope and unfavorable geology and geomorphology in this zone.

$\checkmark \quad$ These prospective groundwater zones can provide a basis for the detailed hydrogeological and/or geophysical investigations needed for well sitting and proper management of scarce groundwater resources.

$\checkmark \quad$ The above results shows that the study area is having moderate to good ground water potential zones.

$\checkmark$ The VES locations 9 and 10 are well suited for having borewells, because the maximum thickness of deep fractured zone is obtained in these locations.

As a post-script result, it is given to understand that the location VES9 \& VES10 has been drilled. Water of 6000 litres per hour is drawn from that borewell. Hence, it is concluded that the computer modelling of groundwater occurrences using geophysical parameters is successful in the Gangaikondan and Manur block, Tirunelveli disrtict, Tamil Nadu, South India.

\section{REFERENCES}

Ahilan.J and Senthil Kumar.G.R (2011). Identification of aquifer zones by VES method: A case study from Mangalore block, Tamil Nadu, S. India. Archives of Applied Science Research. Vol.3 (2), pp.414-421.

Ariyo, S.O. and Adeyemi, G.O (2009). The Role of Electrical resistivity method for groundwater exploration in hard rocks areas. A case study from Fidiwo/Ajebo 
areas of Southwestern Nigeria. The Pacific Journal of Science and Technology; 10 (1):483-486.

Balasubramanian.A, Sharma.K.K. and Sastri, J.C.V. (1985) Geoelectrical and hydrogeochemical evaluation of coastal aquifers of Tambraparani basin, Tamilnadu, Geophy. Res. Bull. 23(4): 203-209.

Batte.A.G, Muwanga.A and Sigrist.W.P (2008). Evaluating the use of vertical electrical sounding as a groundwater exploration technique to improve on the certainty of borehole yield in kamuli district (eastern uganda). African Journal of Science and Technology. Vol.9, No.1, pp.72-85.

Caglayan Balkaya, Ali Kaya.M and Gokhan Gokturkler (2009). Delineation of shallow resistivity structure in the city of Burdur, SW Turkey by vertical electrical sounding measurements. Environ Geol. Vol. 57, pp.571581.

Das.S.N, Mondal.S.N and Singh.V.S (2007). Groundwater Exploration in Hard Rock Areas of Vizianagaram District, Andhra Pradesh, India. Journal of Indian Geophysics Union. Vol.11, No.2, pp.79-90.

Ekwe.A.C, OnuN.N and Onuoha.K.M (2006). Estimation of aquifer hydraulic characteristics from electrical sounding data: the case of middle Imo River basin aquifers, south- eastern Nigeria. Journal of Spatial Hydrology. Vol.6, No.2, pp. 120-132.

Jha. Madan K, Kumar.S, and Chowdhury.A (2007). Vertical electrical sounding survey and resistivity inversion using genetic algorithm optimization technique. Journal of Hydrology. Vol. 359, pp.7187.

Lashkaripour (2003). An investigation of groundwater condition by geoelectrical resistivity method: A case study in Korin aquifer, southeast Iran. Journal of Spatial Hydrology. Vol.3, pp.15.

Mondal.N.C, Das.S.N and Singh.V.S (2008). Integrated approach for identification of potential groundwater zones in Seethanagaram Mandal of Vizianagaram District, Andhra
Pradesh, India. J. Earth Syst. Sci. 117, No. 2, pp. 133144.

Senthilkumar,M · L. Elango, (2004) Threedimensional mathematical model to simulate groundwater flow in the lower Palar River basin, southern India, Hydrogeology Journal, Vol. 12, pp.197208.

Srinivas.Y, Muthuraj.D and Chandrasekar.N (2008). Resistivity studies to delineate structural features near Abhishekapatti, Tirunelveli, Tamil Nadu, India.

Yusuf.S.N, Joseph.M.V, Alkali.S.C and Kuku.A.Y (2011). Determination of porous zones using vertical electrical sounding data from basement rocks of hussara, askira uba, north-eastern Nigeria. Ozean Journal of Applied Sciences. Vol.4(2),pp.183-189. 